\title{
AKIBAT HUKUM PEMBATALAN HIBAH ISTRI TERHADAP SUAMI SETELAH ADANYA PERCERAIAN (ANALISIS KASUS : PUTUSAN MAHAKAMAH AGUNG NOMOR 1893 K/PDT/2015)
}

\author{
Oleh: \\ Julian Albert Dewantara \\ I Made Sarjana \\ I Nyoman Darmadha \\ Bagian Hukum Perdata Universitas Udayana
}

\begin{abstract}
ABSTRAK
Putusan Mahkamah Agung Nomor 1893 K/PDT/2015 yang mengadili perkara penghibahan antara I Gusti Ayu Ita Dewi dengan Sven Hollinger suaminya. Metode penelitian yang digunakan dalam penyusunan jurnal ini adalah metode penelitian normatif.

Adapun permasalahan yang dibahas dalam penelitian ini yaitu, pengaturan hukum mengenai perjanjian hibah yang dilakukan oleh istri kepada suami setelah adanya perceraian dan akibat hukum dari perjanjian hibah suami-istri yang batal demi hukum atas obyek hibah.

Penghibahan yang dilakukan oleh suami istri adalah dilarang berdasarkan ketentuan Pasal 1678 Kitab Undang-Undang Hukum Perdata maka termasuk perbuatan melawan hukum yang mengakibatkan perjanjian hibah tersebut batal demi hukum sehingga mengharuskan para pihak untuk mengembalikan obyek hibah kepada keadaan semula sebelum terjadinya penghibahan.
\end{abstract}

Kata Kunci: Perjanjian Hibah, Akibat Hukum, Batal Demi Hukum

ABSTRACT
Supreme Court Decision Number $1893 \mathrm{~K} / \mathrm{PDT} / 2015$ which tried the granting case between I Gusti Ayu Ita Dewi and Sven Hollinger her husband. The research method used in the preparation of this journal is a normative research method.

As for the problems discussed in this study is the legal consequences if the grant agreement is said to be illegal and the legal consequences of the husband and wife grant agreement null and void on the object of the grant.

The grant made by husband and wife was prohibited based on the provisions of Article 1678 of the Civil Code so that it included illegal acts which resulted in the grant agreement being null and void. The grant agreement that is null and void requires the parties 
to return the object of the grant to its original state before the grant agreement was made.

Keywords: Grant Agreement, Legal Consequences, Null and Void

\section{I.PENDAHULUAN}

\subsection{Latar Belakang Masalah}

Hibah diartikan sebagai pemberian secara perjanjian, yang mana pihak yang satu menyetujui dengan cuma-cuma dan mutlak memberikan suatu benda kepada pihak lainnya sebagai penerima pemberian tersebut, sehingga sebagai suatu perjanjian pemberian tersebut mengikat kedua belah pihak dan tidak dapat ia cabut kembali menurut kehendak satu pihak saja ${ }^{1}$. Menurut ketentuan Pasal 1666 Kitab Undang-Undang Hukum Perdata, hibah adalah suatu persetujuan dengan mana seorang penghibah menyerahkan suatu barang secara cuma-cuma tanpa dapat menariknya kembali, untuk kepentingan seseorang yang menerima penyerahan barang itu dan Undang-Undang hanya mengakui penghibahan antara orang yang masih hidup. Menurut pendapat CST Kansil hibah merupakan perjanjian oleh pihak pertama akan menyerahkan suatu benda karena kebaikannya kepada pihak lain yang yang menerima benda tersebut ${ }^{2}$. Dari penjelasan tersebut diatas dapat dilihat unsur-unsur dari hibah, yaitu merupakan persetujuan untuk menyerahkan suatu barang secara cuma-cuma yang artinya tidak ada kontra prestasi atau penerima hibah tidak ada kewajiban apapun untuk menerima hibah tersebut, hibah dilakukan dengan maksud dari penghibah untung menguntungkan pihak penerima hibah, yang menjadi objek hibah adalah segala macam barang atau harta benda milik penghibah

\footnotetext{
${ }^{1}$ Subekti, 1975, Pokok-Pokok dari Hukum Perdata Cetakan Ke-11, Intermassa, Bandung, h. 138

${ }^{2}$ C.S.T. Kansil, 2002, Pengantar Ilmu Hukum Dan Tata Hukum Indonesia, Balai Pustaka, Jakarta, h.252
} 
bisa juga termasuk piutang penghibah tergantung isi dari perjanjian hibah tersebut, hibah tidak dapat ditarik kembali, penghibahan harus dilakukan pada saat para pihak masih hidup namun pelaksanaannya masih dapat dilakukan dalam kondisi pemberi hibah sudah meninggal dunia, dan yang terakhir adalah hibah harus dilakukan dihadapan notaris. Jadi undang-undang hanya mengakui penghibahan antara orang-orang yang masih hidup. Serah terima barang merupakan syarat pelaksanaan dan sempurnanya hibah ${ }^{3}$.

Didalam kasus ini, terdapat gugatan pengembalian hibah oleh seseorang bernama I Gusti Rai Tantra kakak kandung dari seorang istri yang bernama Gusti Ayu Ita Dewi yang melakukan penghibahan terhadap suaminya yang bernama Sven Hollinger. Ketika akan melangsungkan perkawinan mereka membuat perjanjian perkawinan yang isinya bahwa mereka sepakat untuk memisahkan harta kekayaan mereka. Selama masa perkawinan berlangsung, pada tahun 2011 terjadi penghibahan yang dilakukan oleh si istri I Gusti Ayu Ita Dewi terhadap suaminya Sven Hollinger. Penghibahan ini dilakukan dihadapan notaris atas beberapa bidang tanah dan rumah. Permasalahan terjadi ketika terjadi perceraian, kakak kandung dari istri mengajukan gugatan untuk pengembalian harta hibah tersebut dengan alasan bahwa harta tersebut adalah harta pemberian dari keluarganya kepada I Gusti Ayu Ita Dewi untuk membantu adiknya dalam segi ekonomi dengan kesepakatan agar tidak diberikan kepada orang lain.

Dalam Kitab Undang-Undang Hukum Perdata disebutkan siapa saja yang dinyatakan tidak mampu untuk menerima atau memberi penghibahan. Penghibahan antara suami isteri selama masa perkawinan masih berlangsung dilarang oleh undang-

${ }^{3}$ Rosnidar Sembiring, 2016, Hukum Keluarga : Harta-harta Benda dalam Perkawinan, PT. RajaGrafindo Persada, Jakarta, h.108 
undang, tetapi ketentuan ini tidak berlaku terhadap pemberian barang bergerak yang berwujud dan yang harganya tidak mahal atau tidak melampaui besarnya kekayaan penghibah. Didalam undang-undang juga dijelaskan bahwa hibah hanya dapat dilakukan terhadap harta benda yang sudah ada, jika benda hibah tersebut baru akan ada dikemudian hari maka perjanjian hibah tersebut dianggap batal. Banyak dalam praktek oleh masyarakat pemberian hibah antara suami isteri dengan alasan sebagai bukti kasih sayang terhadap suaminya atau isterinya, namun hal ini berarti cukup banyak masyarakat kita belum mengetahui mengenai aturan yang berlaku tentang hal ini.

\subsection{Rumusan Masalah}

1. Bagaimana pengaturan hukum mengenai perjanjian hibah yang dilakukan oleh istri kepada suami setelah adanya perceraian?

2. Apa akibat hukum dari perjanjian hibah suami-istri yang batal demi hukum atas obyek hibah ?

\subsection{Tujuan Penulisan}

1. Untuk menganalisis dan mengetahui mengenai akibat hukum dari perjanjian hibah suami-istri setelah adanya perceraian.

2. Untuk menganalisis serta mengetahui akibat hukum dari perjanjian hibah yang dibatalkan demi hukum atas obyek hibah suami-istri.

\section{II.ISI MAKALAH}

\subsection{Metode Penelitian}

Dalam jurnal ilmiah ini digunakan jenis penelitian normatif. Penelitian normatif adalah penelitian hukum kepustakaan ${ }^{4}$. Penelitian hukum normatif mempelajari norma-norma dan aturan-

\footnotetext{
${ }^{4}$ Soerjono Soekanto dan Sri Mamuji, 2006, Penelitian Hukum Normatif, Raja Grafindo Persada, Jakarta, h.23
} 
aturan yang ada yang dengan menggunakan pendekatan perundang-undangan didalam mengumpulkan dan menganalisis bahan hukum.

\subsection{Hasil dan Pembahasan}

\subsubsection{Pengaturan Hukum Perjanjian Hibah Yang Dilakukan Istri Kepada Suami Setelah Adanya Perceraian.}

Ketentuan Kitab Undang-Undang Hukum Perdata Pasal 1678, penghibahan yang dilakukan oleh suami-istri selama masa perkawinan masih berlangsung dilarang, kecuali untuk barang bergerak yang nilai nya tidak melebihi kekayaan si penghibah. Didalam pasal tersebut sudah sangat jelas adanya larangan untuk melakukan perjanjian penghibahan antara suami istri yang masih terikat dalam suatu ikatan perkawinan, sehingga penghibahan antara suami-istri adalah sebuah perbuatan melawan hukum.

Suatu perjanjian yang dianggap sebagai perbuatan melawan hukum, berdasarkan ketentuan Pasal 1320 Kitab Undang-Undang Hukum Perdata tentang syarat sah nya perjanjian pada poin yang keempat yaitu suatu sebab yang tidak terlarang, maka perjanjian hibah antar suami istri tersebut tidak memenuhi syarat sah perjanjian tersebut sehingga mengakibatkan perjanjian tersebut batal demi hukum. Suatu kontrak tanpa suatu kausa yang legal merupakan kontrak yang batal demi hukum ${ }^{5}$.

Batal demi hukum adalah ketika sesuatu menjadi tidak berlaku dan/atau tidak sah karena menurut hukum memang begitu adanya ${ }^{6}$. Apabila perjanjian batal demi hukum, artinya dari semula tidak pernah dilahirkan suatu perjanjian, dan dengan demikian tidak pernah ada suatu perikatan. Dalam hal ini ada

\footnotetext{
${ }^{5}$ Munir Fuady, 2015, Hukum Kontrak Buku Kesatu, PT. Citra Aditya Bakti, Bandung, h.60

${ }^{6}$ Elly Erawati dan Herlien Budiono, 2010, Penjelasan Hukum Tentang Kebatalan Perjanjian, Nasional Legal Reform Program, Jakarta, h.1
} 
beberapa alasan mengapa suatu perjanjian menjadi batal demi hukum, yaitu :

a) Batal demi hukum karena syarat perjanjian formil tidak terpenuhi. Perjanjian formil disini maksudnya bukan mengenai perjanjian tersebut didasarkan atas kesepakatan para pihak, tetapi mengenai oleh Undang-Undang disyaratkan sebuah formalitas tertentu yang harus dipenuhi agar perjanjian tersebut sah secara hukum 7 . Formalitas terebut misalnya tentang bentuk atau format perjanjian yang harus dibuat dalam bentuk tertentu, yakni dengan akta otentik. Akta otentik adalah akta yang dibuat oleh notaris atau pejabat lain yang diberi wewenang menurut Undang-Undang.

b) Batal demi hukum karena syarat obyektif sahnya perjanjian tidak terpenuhi. Menurut Pasal 1320 Kitab Undang-Undang Hukum Perdata, pada poin keempat, suatu perjanjian dianggap sah secara hukum apabila mengatur suatu hal tertentu dan suatu sebab yang tidak terlarang, maka apabila syarat obyektif ini tidak terpenuhi perjanjian tersebut batal demi hukum. Hal ini dipertegas dalam Pasal 1335 Kitab Undang-Undang Hukum Perdata yang memuat "suatu perjanjian tanpa sebab atau yang telah dibuat karena suatu sebab yang palsu atau terlarang, tidak mempunyai kekuatan”. Kemudian pada Pasal 1337 Kitab UndangUndang Hukum Perdata mengatakan bahwa suatu sebab adalah terlarang apabila suatu sebab tersebut dilarang oleh Undang-Undang atau bertentangan dengan kesusilaan atau ketertiban umum.

\footnotetext{
${ }^{7}$ Ibid, h.6
} 
c) Batal demi hukum karena dibuat oleh orang yang tidak berwenang melakukan perbuatan hukum. Mengenai hal ini harus dimengerti bahwa antara ketidakcakapan seseorang dan ketidakwenangan seseorang untuk melakukan perbuatan hukum adalah dua hal yang berbeda. Orang yang tidak berwenang disini artinya adalah orang yang oleh Undang-Undang dilarang melakukan tindakan hukum tertentu ${ }^{8}$. Contoh : Undang-Undang Nomor 23 Tahun 1999 tentang bank Indonesia, Pasal 55 yang memuat “(4)Bank Indonesia dilarang membeli untuk diri sendiri surat-surat utang negara sebagaimana dimaksud pada ayat (1), kecuali di pasar sekunder. (5)Perbuatan hukum Bank Indonesia membeli surat utang negara untuk diri sendiri tidak di pasar sekunder sebagaimana dimaksud pada ayat (4), dinyatakan batal demi hukum”. Pasal 56 "(1)Bank Indonesia dilarang memberikan kredit kepada Pemerintah. (2)Dalam hal Bank Indonesia melanggar ketentuan sebagaimana dimaksud pada ayat (1), perjanjian pemberian kredit kepada Pemerintah tersebut batal demi hukum".

d) Batal demi hukum karena ada syarat batal yang terpenuhi. Syarat batal dalam sebuah perjanjian disini maksudnya adalah suatu kondisi yang belum tentu terjadi dimasa depan namun para pihak dalam perjanjian tersebut sepakat bahwa apabila kondisi tersebut terjadi dikemudian hari maka perjanjian tersebut menjadi batal ${ }^{9}$.

Berdasarkan Putusan Pengadilan Tinggi Denpasar Nomor 04/PDT/2015/PT.DPS jo. Putusan Mahkamah Agung Nomor 1893 K/Pdt/2015 yang penulis analisa, terjadi penghibahan yang

\footnotetext{
${ }^{8}$ Ibid, h.13

${ }^{9}$ Ibid
} 
dilakukan oleh istri yaitu I Gusti Ayu Ita Dewi warganegara Indonesia kepada suaminya Sven Hollinger yang sudah mendapatkan status kewarganegaraan Indonesia. Ketika masa perkawinan masih berlangsung terjadi penghibahan dan yang menjadi obyek hibah nya adalah beberapa bidang tanah dan saham perusahaan, yang dibuat dihadapan Notaris I Dewa Putu Oka Diatmika, SH yang kemudian dibuatkan akta perjanjian hibah nya. Berdasarkan akta perjanjian hibah tersebut dapat diketahui bahwa ketika dilakukannya hibah yaitu pada saat masa perkawinan masih berlangsung sehingga sesuai dengan ketentuan Kitab Undang-Undang Hukum Perdata, yaitu atas dasar Pasal 1678, penghibahan yang dilakukan oleh istri I Gusti Ayu Ita Dewi kepada suami Sven Hollinger ketika masa perkawinan adalah dilarang. Kemudian mengenai benda yang menjadi obyek penghibahan, yaitu berupa beberapa bidang tanah yang tergolong benda tidak bergerak (berdasarkan pasal 506 Kitab UndangUndang Hukum Perdata) dan saham perusahaan, yang melebihi nilai kekayaan dari I Gusti Ayu Ita Dewi, mengakibatkan pengecualian dalam Pasal 1678 tidak berlaku. Hal ini mengakibatkan harta kekayaan yang semula dinikmati bersama ketika masih berkawin setelah terjadinya perceraian menjadi tidak dapat lagi dinikmati oleh I Gusti Ayu Ita Dewi, kemudian dilakukan tuntutan oleh kakak kandung I Gusti Ayu Ita Dewi yaitu I Gusti Rai Tantra untuk pembatalan hibah suami-istri tersebut, dengan dalil bahwa benda yang dihibahkan tersebut adalah pemberian dari keluarga untuk membantu perekonomian dari I Gusti Ayu Ita Dewi, sehingga pihak keluarga merasa dirugikan karena benda yang diberikan kepada I Gusti Ayu Ita Dewi telah dihibahkan kepada Sven Hollinger ketika masih berstatus sebagai suami-istri. 
Setelah mengetahui bahwa penghibahan yang dilakukan oleh istri I Gusti Ayu Ita Dewi kepada suami Sven Hollinger adalah dilarang oleh Pasal 1678 Kitab Undang-Undang Hukum Perdata, maka akibat hukum nya adalah penghibahan tersebut dianggap sebagai perbuatan melawan hukum. Dalam Putusan Mahkamah Agung Nomor 1893 K/Pdt/2015 telah dinyatakan oleh sidang majelis hakim bahwa penghibahan yang dilakukan oleh suamiistri I Gusti Ayu Ita Dewi dan Sven Hollinger adalah perbuatan melawan hukum.

Sebagai perbuatan melawan hukum, maka perjanjian hibah tersebut tidak memenuhi syarat sah nya perjanjian berdasarkan ketentuan Pasal 1320 Kitab Undang-Undang Hukum Perdata, poin keempat yaitu suatu sebab yang tidak terlarang, sehingga perjanjian hibah antara suami istri tersebut batal demi hukum. Seperti yang termuat dalam Putusan Mahkamah Agung Nomor 1893 K/Pdt/2015, menyatakan semua Akta Hibah yang sudah dibuat dihadapan Notaris I Dewa Putu Oka Diatmika, SH atas tiga bidang tanah dan saham sebuah perusahaan tersebut batal demi hukum dan tidak mempunyai kekuatan mengikat beserta segala akibat hukumnya. Berbeda sudut pandang secara hukum apabila Sven Hollinger disini belum memiliki status warga negara Indonesia, maka perjanjian pokok yang diikuti dengan perjanjian lain terkait dengan penguasaan hak milik atas tanah oleh warga negara asing menunjukkan bahwa secara tidak langsung melalui perjanjian notariil telah menjadi penyelundupan hukum ${ }^{10}$.

\subsubsection{Akibat Hukum Dari Perjanjian Hibah Suami-Istri Yang Batal Demi Hukum Atas Obyek Hibah.}

Dalam Putusan Mahkamah Agung Nomor 1893 K/Pdt/2015, selain menyatakan batal demi hukum atas perjanjian hibah antara

\footnotetext{
${ }^{10}$ I Wayan Werasmana Sancaya, 2013, Kekuatan Mengikat Perjanjian Nominee Dalam Penguasaan Hak Milik Atas Tanah, Jurnal Magister Hukum Udayana Vol. 2 No. 3, Denpasar, h. 3
} 
I Gusti Ayu Ita Dewi kepada suami nya Sven Hollinger, Majelis Hakim juga menyatakan segala perbuatan hukum yang didasari atas akta perjanjian dan akta kuasa antara I Gusti Ayu Ita Dewi dan suaminya Sven Hollinger, adalah tidak sah dan tidak mempunyai kekuatan hukum mengikat dengan segala akibat hukumnya. Adalah wajar apabila kemudian segala perbuatan hukum yang didasari oleh akta tersebut menjadi tidak sah, mengingat bahwa akta perjanjian hibah yang mereka lakukan sudah dinyatakan batal demi hukum oleh Majelis Hakim, sehingga sudah tidak ada lagi dasar hukum atas perbuatan hukum yang dilakukan berdasarkan penghibahan tersebut. Hal ini juga termasuk perubahan kepemilikan hak atas tanah dari pencatatan administrasi perubahan kepemilikan hak atas tanah oleh Kepala Kantor Pertanahan Kabupaten Badung, dinyatakan tidak sah dan tidak mempunyai kekuatan hukum mengikat.

Berdasarkan putusan tersebut, seharusnya Majelis Hakim dengan tegas menyatakan menghukum tergugat, yaitu dalam hal ini adalah Sven Hollinger selaku penerima hibah dari isterinya I Gusti Ayu Ita Dewi, untuk mengembalikan segala benda yang telah ia terima akibat dari perjanjian penghibahan tersebut kepada I Gusti Ayu Ita Dewi selaku pemberi hibah, dalam keadaan bersih tidak ada beban yang melekat atas benda tersebut. Maksud beban yang melekat disini adalah apabila benda tersebut dijadikan jaminan untuk berhutang dan segala macam bentuk beban yang bisa dilekatkan pada tanah karena dalam kasus kali ini benda hibah nya adalah beberapa bidang tanah.Akta hibah yang dibuat dihadapan notaris adalah alat bukti yang sempurna didalam sidang pengadilan. Dalam sebuah akta otentik memiliki kekuatan pembuktian ekstern. Akta otentik mempunyai bentuk tertentu ditetapkan Undang-Undang serta pembuatnya adalah seorang 
pejabat yang berwenang. Akta otentik memiliki kekuatan pembuktian formal, karena pejabat pembuat akta tersebut adalah pejabat yang melakukan tugasnya dibawah sumpah sehingga apa yang dimuat dalam akta itu dianggap sungguh-sungguh diucapkan oleh pihak yang bersangkutan. Lalu akta otentik mempunyai kekuatan pembuktian materiil karena dianggap bukan hanya sekedar ucapan tetapi juga benar-benar terjadi dilakukan oleh para pihak. Akta otentik menjadi bukti sempurna tentang yang termuat didalamnya, bagi para pihak didalam akta tersebut serta ahli waris atau orang yang mendapat hak dari itu, namun akta otentik tidak memiliki kekuatan pembuktian sempurna bagi pihak ketiga ${ }^{11}$. Penerapan hukum seharusnya melindungi hak-hak dan kewajiban setiap subjek hukum sehingga dalam hal satu hukum tertentu diterapkan, seharusnya hukum tersebut hanya berdampak efektif, memperbaiki, membenahi, dan menghukum pihak-pihak yang bermasalah saja tanpa membentur atau mengganggu hak-hak dan kewajiban subjek hukum lain yang sebelumnya tidak mengalami masalah apapun ${ }^{12}$.

\section{III.PENUTUP}

\subsection{Simpulan}

1. Pengaturan hukum perjanjian hibah antara suami-istri termuat dalam pasal 1678 Kitab Undang-Undang Hukum Perdata, yaitu penghibahan antara suami-istri selama perkawinan masih berlangsung dilarang, sehingga perjanjian hibah tersebut merupakan suatu perbuatan melawan hukum yang mengakibatkan perjanjian hibah menjadi batal demi hukum berdasarkan Pasal 1320 Kitab

\footnotetext{
${ }^{11}$ Ibid, h.200-201

${ }^{12}$ Nyoman Samuel Kurniawan, 2014, Konsep Wanprestasi Dalam Hukum Perjanjian dan Konsep Utang dalam Hukum Kepailitan (Studi Komparatif dalam Perspektif Hukum Perjanjian dan Kepailitan), Jurnal Magister Hukum Udayana Vol.3 No.1, Denpasar, h. 18
} 
Undang-Undang Hukum Perdata, yaitu tidak terpenuhinya syarat obyektif sahnya perjanjian pada poin keempat.

2. Akibat hukum dari perjanjian hibah yang batal demi hukum terhadap obyek hibah adalah pengembalian segala status dari obyek tersebut kembali menjadi seperti sebelum adanya perjanjian hibah, bahkan beban-beban yang dilekatkan diatas benda-benda tersebut setelah terjadinya hibah harus dibersihkan.

\subsection{Saran}

1. Dalam mengadakan perjanjian hibah, para pihak, dalam hal ini suami-istri, harus mengerti pengaturan-pengaturan serta akibat-akibat hukum yang dapat muncul dari perjanjian hibah tersebut untuk mencegah terjadinya konflik hukum dikemudian hari, termasuk notaris yang membuatkan perjanjian hibah tersebut seharusnya mengedukasi para pihak mengenai aturan-aturan terkait hibah antara suamiistri.

2. Para pihak yang bersengketa dalam penghibahan antara suami istri agar sebisa mungkin menyelesaikan konflik melalui musyawarah mufakat diluar pengadilan, karena apabila kemudian tidak dapat tercapai permufakatan, maka penyelesaian sengketa akan dilakukan melalui pengadilan dan semua pihak harus mematuhi putusan dari pengadilan tersebut. 


\section{DAFTAR PUSTAKA}

\section{Buku :}

Elly Erawati dan Herlien Budiono, 2010, Penjelasan Hukum Tentang Kebatalan Perjanjian, Nasional Legal Reform Program, Jakarta

Munir Fuady, 2015, Hukum Kontrak Buku Kesatu, PT. Citra Aditya Bakti, Bandung.

Rosnidar Sembiring, 2016, Hukum Keluarga : Harta-harta Benda dalam Perkawinan, PT. RajaGrafindo Persada, Jakarta.

Subekti, 1975, Pokok-Pokok dari Hukum Perdata Cetakan Ke-11, Intermassa, Bandung.

Soerjono Soekanto dan Sri Mamuji, 2006, Penelitian Hukum Normatif, Raja Grafindo Persada, Jakarta.

C.S.T. Kansil, 2002, Pengantar Ilmu Hukum Dan Tata Hukum Indonesia, Balai Pustaka, Jakarta

\section{Jurnal :}

I Wayan Werasmana Sancaya, 2013, Kekuatan Mengikat Perjanjian Nominee Dalam Penguasaan Hak Milik Atas Tanah, Jurnal Magister Hukum Udayana Vol. 2 No. 3, Denpasar.

Nyoman Samuel Kurniawan, 2014, Konsep Wanprestasi Dalam Hukum Perjanjian dan Konsep Utang dalam Hukum Kepailitan (Studi Komparatif dalam Perspektif Hukum Perjanjian dan Kepailitan), Jurnal Magister Hukum Udayana Vol.3 No.1, Denpasar.

\section{Perundang-undangan :}

Undang-Undang tentang Perkawinan, Undang-Undang Nomor 1 Tahun 1974, Lembaran Negara Republik Indonesia Tahun 1974 Nomor 1

Kitab Undang-Undang Hukum Perdata, (Staatblad 1847 Nomor 23)

\section{Bahan Hukum Lainnya:}

Putusan Mahakamah Agung Nomor 1893 K/PDT/2015, Tanggal 26 November 2015 